\title{
特集 一血管透過の解析一
}

\section{免疫グロブリンを tracer とした血管 透過性の形態学的観察*}

\author{
渡辺慶一** 渡辺昌** 相羽元 彦*** \\ 大石隆 夫块 影比圭 三***
}

Key words : permeability test, immunoglobulin as a tracer

血管透過性の推察には，通常，エヴァンス・ ブルーとか, ポンタミン・スカイブルーといら ような生体染色色素類や，成分として，carbon 粒子を含む墨汁，インクなどが tracer として用 いられている。ささらに，最近では，電子顕微 鏡钼察を目的として, Horseradish peroxidase $(\mathrm{HrP})^{1) 22}$, Frerritin ${ }^{3)}$ あるいは，他動物から得 られる cytochrome c, myoglobin ${ }^{4) 5)}$ なども便 用されているが，これらの物質は，透過性の钼 察を受ける生体にとっては，いづれも外来性の 異物であり，大なり小なり，血管壁や，血液 成分に変化をもたらすことが考えられる。ささ に，血液中の物質之，分子量も違光ば，また， 生物, 化学的性状も異る故, 血液血漿成分とは 買った血管透過を示す河能性もある。またこ の点では翼常がないにしても，血管を通過し， 間質へ出た後のこれら tracers の動態は, 浸出 する自己血漿成分のそれとは，かなり異ったも のであることが孚想される。すなわち，㓋物に 対しては，マクロファージ $(M \phi)$, 白血球のよ らな phagocytes は，積極的な貣食作用を示す であろらし，貧食後の二次的な変化（例光ば, lysosomal enzymes の細胞内外への放出など) による血管を含め, 周囲組織への種々の程度の
影響のあることも予期される。これらの危惧を 除き，もっとも自然な形で血管透過性をとら え，透過後の浸出物の動態を正確にとらえるに は，血獎中の成分の何かを marker として観察 するのが，理にかなっているといえよう，そこ で，著者らは，血清中の immunoglobulin をさ らに，最近では， albaminを tracer として， 血管透過性のみならず, 浸出物の詝留から来る 組織の水腫の状態を钼察する方法を考案し た。

\section{I. 材料と方法}

実験動物としては,いずれの場合も200〜250 g の Sprague-Dawley 系雄ラットを用い, これ らの片沞のみに， 1,000 r，2,000 r あるいは， 3, $000 \mathrm{r}$ のX線照射を加えた。この照射により, 初期から照射肺にのみ水腫が迅るが，3,000r の 場合には，肺胞上皮の变性，壞死と，肺胞隔壁 の水腫が殊に強く，またこれが長期間（8週以 上）持続し， $6 \sim 8$ 週後には，それと見合う場 所にびまん性の線維化を認めた。 $2,000 \mathrm{r}$ 以下 の場合には，水腫が起っても，それ程強くな く，また，2週以上持続するものも少く，線維 化は殆ど見られなかった。 また，照射されなか

* Morphological observations on vascular permeability using immunoglobulin as a tracer.

** 東海大学医学部病理, Keiichi Watanabe and Akira Watanabe: Department of Pathology, School of Medicine, Tokai University, Sagamihara, Japan.

*** 管応大学医学部病理, Motohiko Aiba, Takao Oishi and Keizo Kageyama: Department of Pathology, School of Medicine, Keio Universty, Tokyo, Japan. 
$6: 108$

表 1 Preparation of rat serum albumin fraction

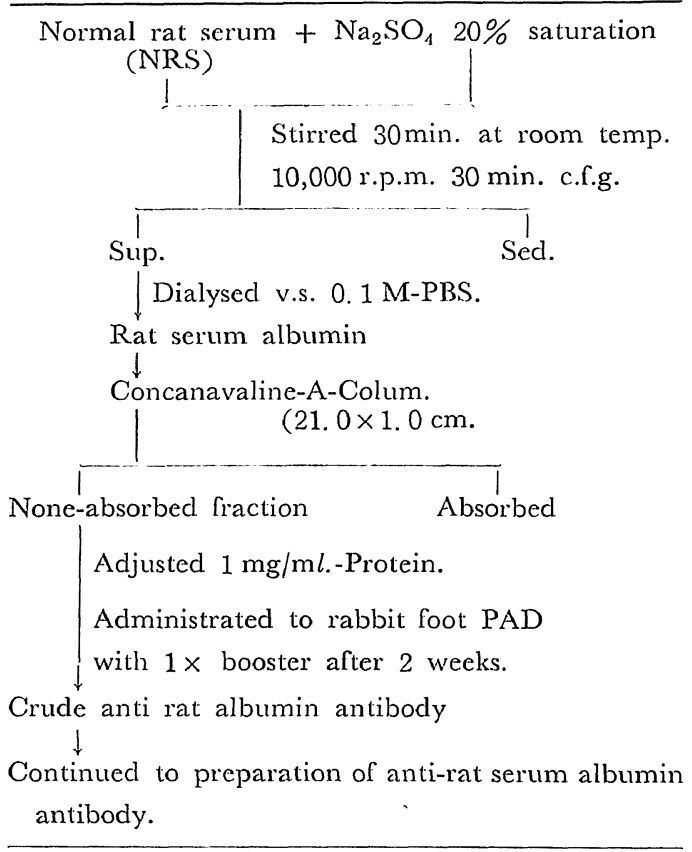

った左肺には，水腫も線維化も認められなかっ た。 照射後， $1 ， 3$ 日，1，2，4，6，8週の各 洔点で動物を稉殺し，右肺（照射肺）を取り出 し，血管透過性，水腫の状態を次の 3 つの物 質を marker として, 形態学的に钼察した：

I. Tracer として HrP を用いる．II. 血清非の immunoglobulin, 括よび. III. Albumin。なお， いづれの場合も，左肺（非照射側）を刘照钼察 に供した。

\section{Tracer として, 外来性酵素蛋白の $\mathrm{HrP}$ を} 用いる実験

精製 HrP としては, Sigma 社 Type VI を 用い, $10 \mathrm{mg} / \mathrm{ml}$ の割合で生食水に溶解し，こ れを照射後各時点にある動物の尾静脈より注入 し30，60，120分，㧍よび24封間後に，動物を 屠殺し，照射右肺と，刘照として非照射左謧に おける tracer HrP の局在を, 光学顕微鏡, 抒 よび電子顕微鏡レベルに打ける酵素細胞化学 (Graham-Karnovsky 法6) ${ }^{6}$ ) で, 観察した。

\section{Immunoglobulin tracer とした観察}

Immunoglobulin を形態学的に観察できる marker とするため, 動物を HrP で免疫し, 血 清中に，充分高い anti-HrP 抗体洒が得られる
血液と脈管第 6 巻第 2 号

表 2 Preparation of anti-rat serum albumin antibody

Rat serum albumin Immuno-electrophoreses $\downarrow$

Immune complex of rat serum albumin (RSA)

And anti-RSA was obtained $\downarrow$

Emulsified complex with Freund's adjuvant $\downarrow$

RE-Administrated to rabbit foot PAD with $\times 1$

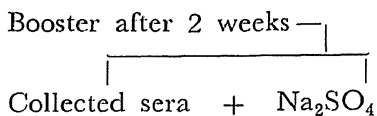

Collected sera $+\mathrm{Na}_{2} \mathrm{SO}_{4} 20 \%$ saturation

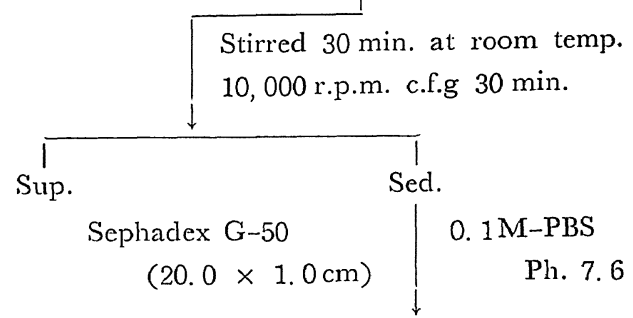

Purified anti-rat serum albumin antibody.

ようにして扣き，この場合, immunoglobulin (Ig) のかなりの部分をしめる anti-HrP 抗体 の局在を, 文献 7) に詳述されている方法で, 光顕的，特よび電顕的に钼察し， Ig の局在と した。な和，HrPによる免疫方法については， $\mathrm{X}$ 線照射時に, 充分高い anti-HrP 抗体便が得 られ，さらに屠殺時まで, 約 3 週ごとに booster shotを繰り返すことにより，それが持続する ような配慮を加えた。

\section{Albumin tracer とした観察}

肺組織笑での albumin (Alb) の局在を钼察 するために, Sprague-Dawley 系ラットの血清 を集め,それから表 1 に記されているような方 法で，精製 Albを取り出し，さらに，それに対 す抗体 (anti-Alb) を表 2 に記されているよう な方法で作製し，HrP ラベル抗体を用いた，醭 素抗体法間接法を採用した。これについては, 電顕钼察はまだ行っていない。

\section{II. 結果および考察}

1. Tracer として, 外来性酵素蛋白の HrP を 用いた実験

未処置のラットの肺，あるいは，鉛板（2.5 


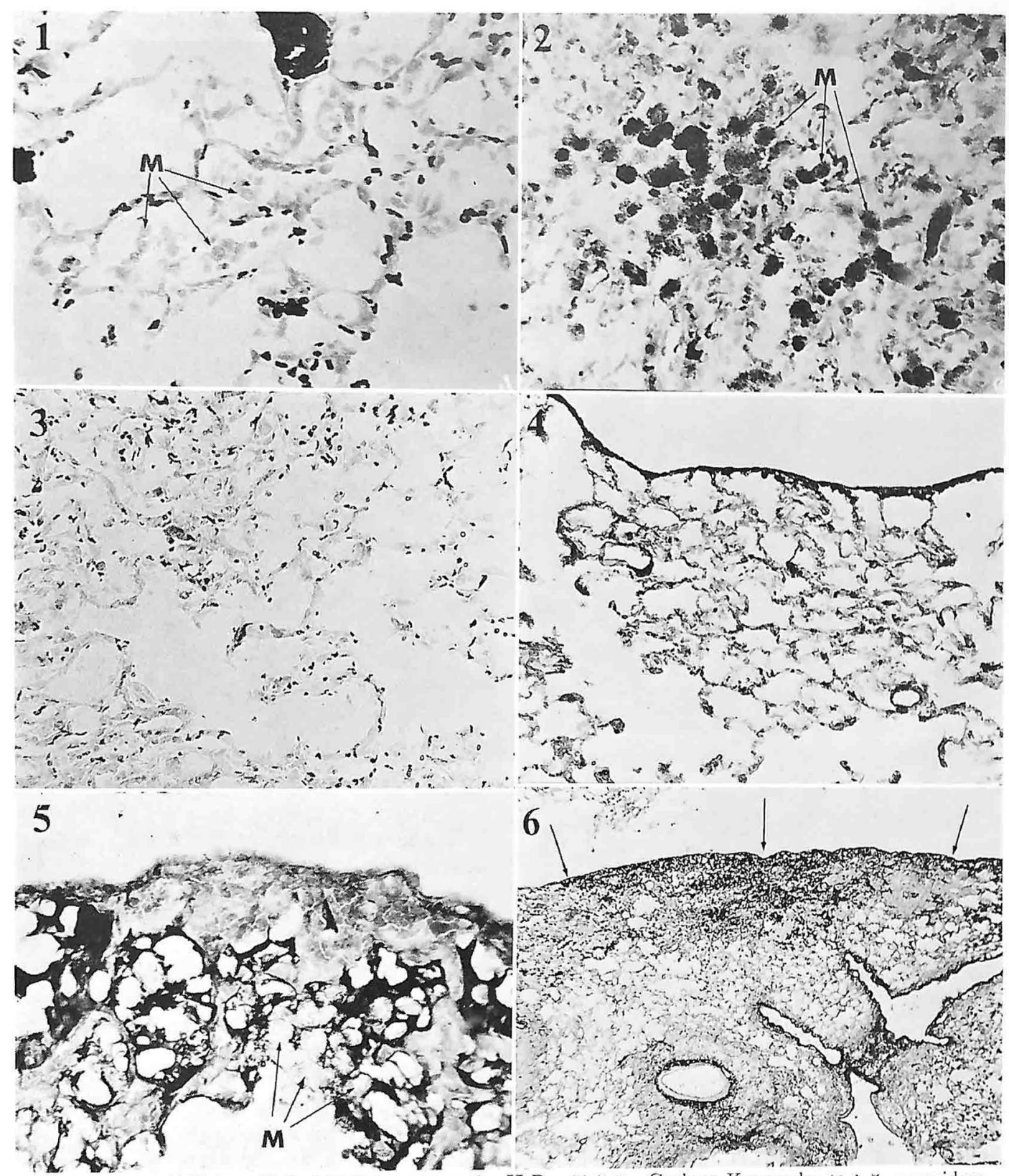

图 1, 2 外来性蛋白の $\mathrm{HrP}$ を将注した動物の肺。 HrP の局在は, Graham-Karnovsky による peroxidase

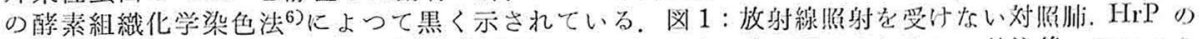

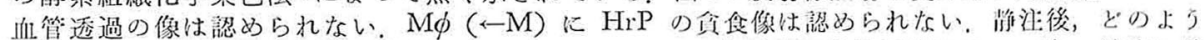

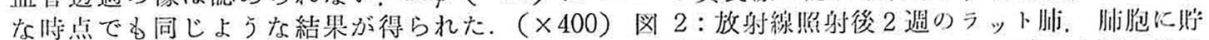

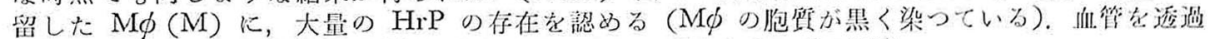
し, 肺胞腔に出た HrP が M に食食されたものと思われる。（×400）

図 3 6 ラット肺 anti-HrP immunoglobulin (Ig) の局在. Anti-HrP の局在は, 免疫反応で, そこに 付着子る抗原 HrP の有子る peroxidase 活性の組織化学的染色法6にによて梌出され，黑く兄え る。図 3: 放射線照射索受けない肺。肺胞隔壁内には，anti-HrP Ig は，ほとんど見当らない。

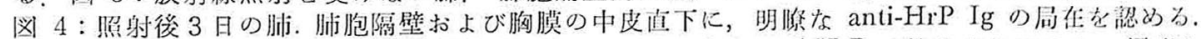
(×200) 図 $5:$ 照射後 4 週の肺。肺胞隔壁は, 芯らに強く anti-HrP で染色されており，浸出し た（血管透過）anti-HrP は肺胞腔内にも充満している。しかし，肺胞腔内の M

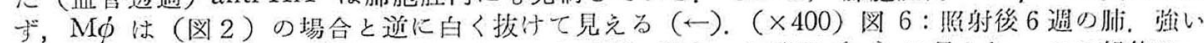

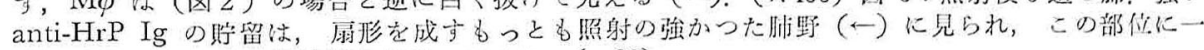
致して，肺のびまん性線維化が起ってくる。( $(\times 32)$ 

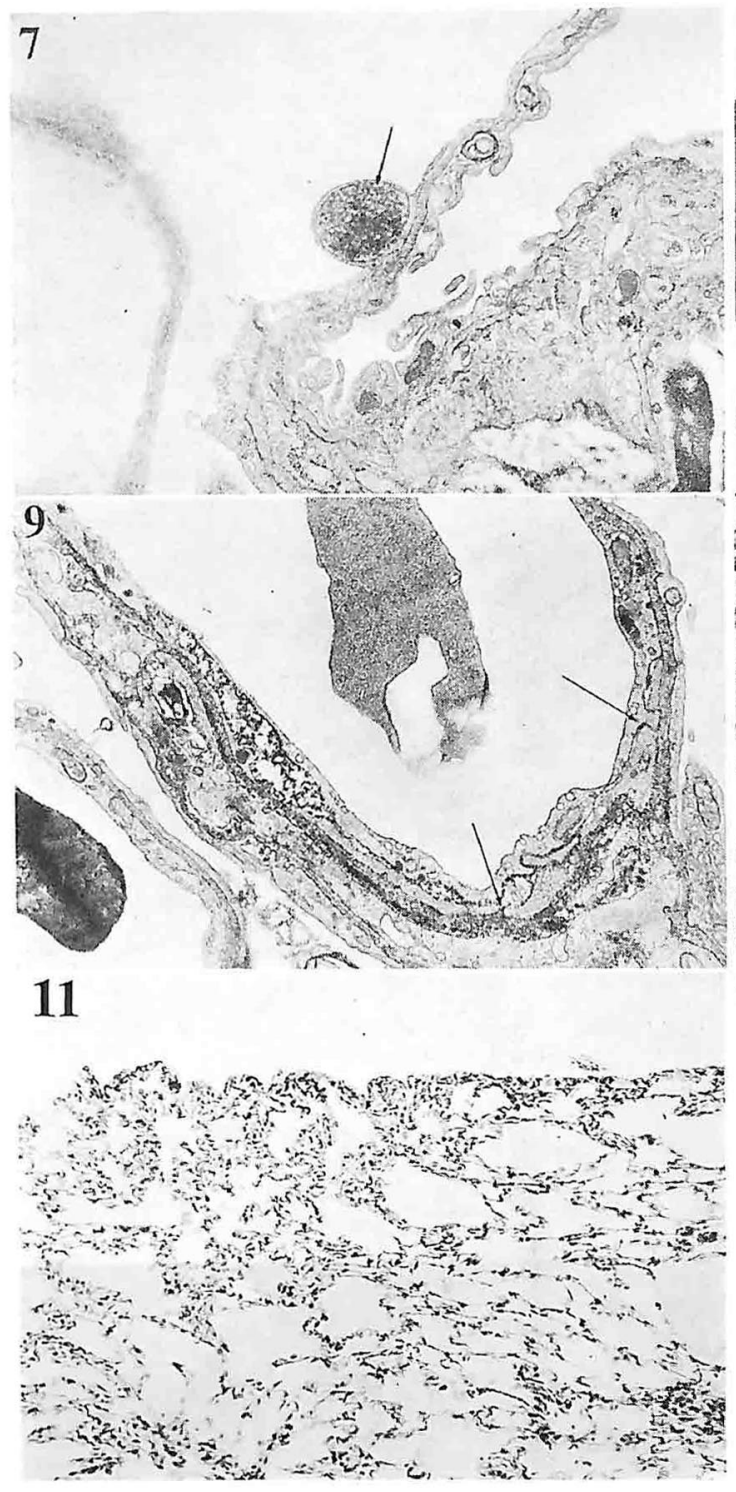

cm/厚）でX線照射を造へいした左樋では，HrP 注入後いずれの將点でも光顕推察では, tracer の $\mathrm{HrP}$ の血管透過の像は認められなかった (図 1 ). 電㩆微察では, 肺胞血管の中に少量の HrPが，認められるが䦌質あるいは，肺胞中に 浚州し， M $\phi$ など phagocytes に徐食された像は 見られない。

照射後短眝日（1日〜1週）のラットについ ては, HrP 注入試験は行わなかったが，照射後 $2 \sim 4$ 週を経たラットで, 肺胞, および㧊胞隔 壁内に著明な水種と，泡沫 $\mathrm{M} \phi$ （主として肺胞
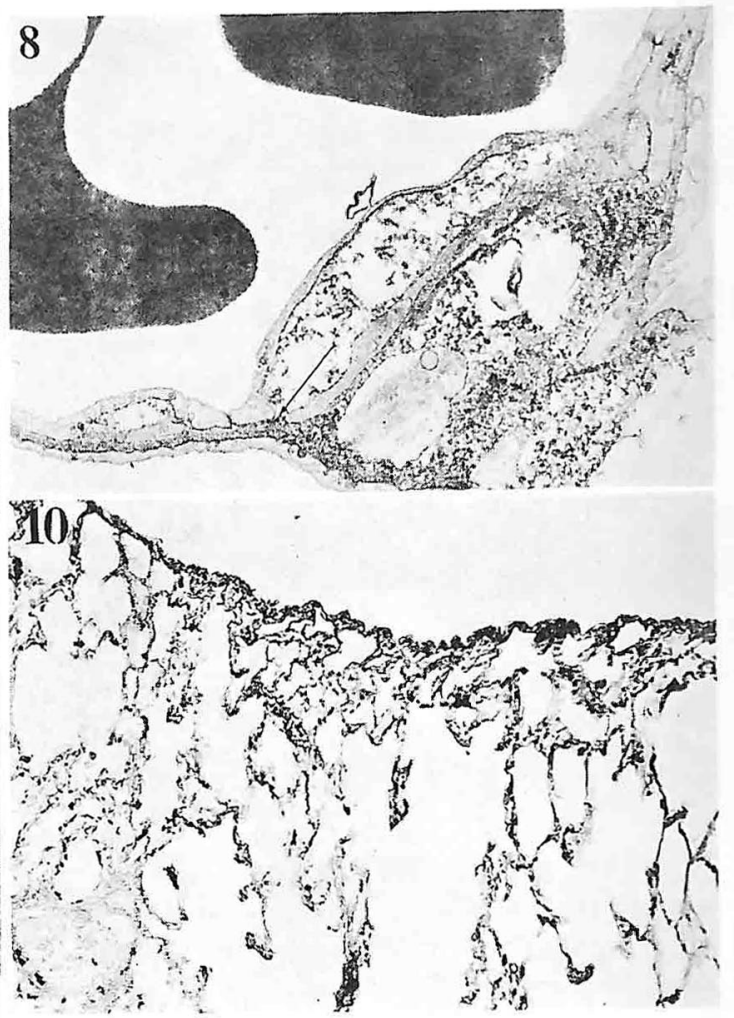

図 7 9 Anti-HrP 局在の電䫓微察. Anti-HrP 局 在部位は，をこに色疫反応によつて付痛する per一

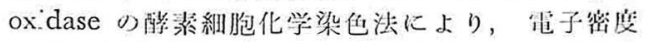
の高い物質（紧貞では黒く見える）として示され ている。四 7 : 照射後 3 日の肺。変性した毛細管

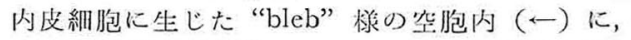
anti-HrP Ig 汸充湍している。 $(\times 19,000)$ 注 8:

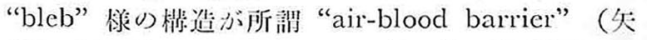
印）と速続しているのがわかる。( $(\times 19,000)$ 因 9：人り組んた内皮の細胞間隕に anti-HrP が冭 满し，これが “air-blood barrier”に速続してい る (-) $(\times 17,000)$

図 10, 11 放船線照射肺に括け尚 albumin の局在 を, HrP labeled antibody (ペルォキシダーゼ・ ラベル抗体）它用いた酳菜抗体間接法で示したも の. Albumin の局在は, やはり，抗体にラベル された HrP の䤑素組織化学染色に上り黑く見え る. $(\times 200)$ 図 10 : 照射後 1 日の肺. 肺胞隔壁 は，浸出した albumin で可成り強く黒く染色さ れている。図11：写真10で用いた切片と同一組瀻 から得られた切片に行った醉素抗体間接法の対照

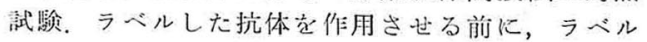
しない抗体で抗原局在部位を十分ブロックした ๖のでむる。明らかに染色性は減退している。 $(\times 200)$ 
内）浸出の見られる肺では，注入された $\mathrm{HrP}$ の大部分は，肪胞内の $M \phi$ と，㑮かながら隔壁 内の $\mathrm{M} \phi$ に貿食されており（図 2)，隔壁の間質 には, 電顕钼察でも， HrP の存在は認められ ない。すなわち，照射䏒では，血管透過性が增 し，注入された HrP は，血管外に浸出してい ることは，上記の結果より明らかだが，その殆 ぞは，異物として $\mathrm{M} \phi$ に貧食されている。した がって HrP のような，異種蛋白を tracer とし て用いた場合，血管透過後の浸出物の正確な動 態を知り得ない。

\section{Igを tracer とした観察}

照射後，ぞの時点でも，鉛板でX線を遮へい した左肺では, anti-HrP 抗体 (Ig) の肺胞内拉 よび隔壁内の局在は認められなかったが(図3). 照射肺（右肪）では，照射後 3 日には，図4 4 に 見られるような，肺胞隔壁は， anti-HrPでか なり強く染っている。これを，電顕で钼察する と， anti- HrP は，I型肺胞上皮と血管内皮の 間の狭いペース (“air-blood barrier”) に, 充洲 している(図 7 )。照射後 2 週では, 可成り厚く なった隔壁は，anti-HrP で，さらに強く染っ ている，照射後 4 週以降になると，Ig（anti$\mathrm{Hr}$ P) の浸出は，肺胞内にも及び，それを充沙

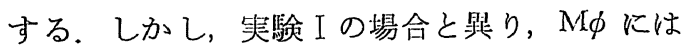
殆ど貧食されず，そこだけが，染色されず淡く 見える(図 5 )。このよらな浸出物の聍留(水蕾) は，リンパ管のある胁膜および，気管支周围 に，もっとも顕著に見られる．照射後 6 週以上 たつと, このような水腫の範囲は, 肋膜に向っ て少し縮少して行き(図6).丁度，それと見合 う領域に，びまん性の線維化が生じて来る。

Ig が浸出を始める初期 (照射後 3 日) の状態 を電顕で観察すると，肺胞血管内皮の胞質内 に，しばしば，“bleb”様の棈造が見られ，その 中に, anti-HrP (Ig) が充渾している（図 7). これらのあるものは, “air-blood barrier”ある いは，拡張した細胞間隙に連続している（図 8, 9).また，このような内皮の胞質には，pinocytotic vesicles が，非常に数を増している. Hüttner らによれば，HrP のような比较的分子量 の小さい（M.W. 40,000) 蛋白が，内皮を通過
する時は，主に細胞間隙を通り， Ferritin のよ らな分子量の大きもの (M. W. 500, 000) の通 過は, pinocytotic vesicles (PV) を介して行な われると言う233)。また, Simionescu, Palade ら が外来性の myoglobin (M.W. 17, 800) を使っ て行った正常心毛細血管内皮の透過性の観察で は，PV と細胞間隙の双方の経路を経て行われ るとしている5)。他にも種々の tracerを使って 血管透過性を電顕で観察した報告があるが，伤

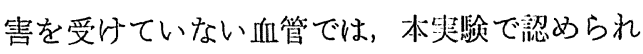
たような“bleb”様の構造に tracer が允洲して いたり，これが細胞間隙や，基底傎側に破れて いるといったような現象は，钼察されていな い.ここでわれわれが，行っている觀察では， 外来性の物質を tracer として用いず，その㿠物 個体の血樂师の Ig tracer として使ってい る故, tracerkよる内皮の伤㫪は栲えられな い，したがって，X線照射による血管透過の促 進は，このような現象を介してひき起されるも のと，思われる。 Tappel らの立澱にも見られ るように，X線照射による free radical の生起 と, これに続いて, 脂酸, 脂啋の (hydro) peroxidation が，起ることは，谷易に想像される ところであり，これが生体膜の生成に渱常をる たらし，その結果 pinocytstic vesiclesによる物 質の transport に支障を来たし，これらの急介 により “bleb”の発生が促されるものと解秋さ れる.

\section{Albumin tracer として行った観察}

X線照射 1 日で早くも図10に見られる如く， 強い albumin の浸出が涩められる。图11は, 写真10と同じ垁験条件の脯組繊片にほどこした 酵素抗体法の刘照試験 (anti-albumin-家货血源 [RGG]ーを作用させた後，HrP をラベルした anti-RGG を作用させる前に，HrPをラベルし ていない anti-RGG で blocking を行ったもの) の結果で，染色性は全然垫められず，したが って, 図11に見られる染色性は, 没出した albumin の存在を示するのである. しかし，Ig の場合と暴り，照射を受けない左棜でも溺いな がら albumin に基く染色性が認められる。笛 顕による钼察に成功していないので，この alb- 
$6: 112$

umin が, 肺胞血管内のものか, 䦌質に浸出し たものか断定できない.

種々の異ったタイプの炎䇛にあって, 同じ血 漿中の成分でも分子量が異り，また生物活性も 翼るIg と, albumin の透過性に相違があるの かどうか精査するのは，これからの課題である.

\section{文献}

1) Karnovsky, M.J.: J. Cell Biol., 35: 213, 1967.

2) Hiittner, I., Boutet, M. and More, R.H.: Lab. Invest., 28: 672, 1973.

3) Bruns, R.R. and Palade, G.E.: J. Cell Biol., 37: 277, 1968.

4) Karnovsky, M.J.: Alfred Benzon Symposium II "Capillary Permeability", Academic Press Inc., New York, p. 341, 1970.

5) Simionescu, N., Simionescu, M. and Palade, G.E.: J. Cell Biol., 57: 424, 1973.

6) Graham, R.C. and Karnovsky, M.J.: J. Histochem. Cytochem., 14: 291, 1966.

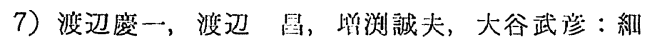
胞, 1974.

\section{＜質疑応答＞}

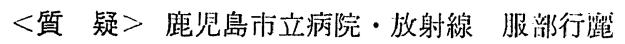

(1) 放射線照射の条件について招教兄下さい（X線か 線でしょらか)。

(2) $3,000 \mathrm{rads} 1$ 回片师照射洔の $\mathrm{LD}_{50}$ はどの程传か？ <応答> 東游大・病理 渡辺鹿一

(1) $\mathrm{X}$ 線 $(250 \mathrm{kV}$ アルミ半過層, あと詳しいことは, 現在覚えて扣りません，島津の深部治療用のもの でず).

(2) 片沞のみの照射では，3,000 rでもほとんどがそ のまま生存いたしました。

<質 疑> 九大・病理 田中健藏

(1) Blood-air barrier には，毛細血管内皮細胞層，基 底膜，肺胞上皮細胞層の三者が関係すると考えら れるが，放射線を照射した場合に，肺胞上皮層の 透過性の変化はどらでずか。

(2) 胞壁への immunoglobulin の沈着はどのような経 過を経て沈着するのですか，基底膜自身の透過性 に変化はありませんか。

<応 答 $>$ 東海.大. 病理 渡辺慶一

(1) いわゆるI望肺胞上皮 (membranous pneumocyte）には血管内皮に起ったものと同じょうな变 化 (smooth vesicles-pinocytotic vesicles の增加,
血液と脈管第 6 巻第 2 号

技そらくこれらの瘉合によって生じると思われる vacuoles の出現，などが見られ，これらの中に は, やはり免疫グロブリンが含まれている像が観 察された。変化の強いるのは，ついには壊死に陥 る）が見られました。

(2) Immunoglobulin の肺胞血管の通過乣は，2つの 経路があります。（1) Pinocytotic vesicle による vesicular transportation (2)内皮細胞間隙の通過. (1)の場合には，胞質内に “bleb”様の構造ができ， ここに一時大量にためられて,これが B-A barrier の方に破れることも西ります。，また，(2)の場合汇 も，B-A barrier に続く内皮の細胞間隙にも，か なり大きな腔が形成され，ここにも，Imm. Globulin の貯留が見られ，このような腔の巨大化， 血管内外への破裂によって, 内皮細胞の破壊がも たらされるように思えます。

\section{一質 疑>神戸大・病理 京極方久}

血管の透過性を高めた状態で, 内皮細炮の Lumen 側と基底膜側に micropinocytosis が沢山あるのにマ 一カーが peroxydase の場合には，あまりその中に 見られず，たまに見られても cell 内で処理されて 内皮は通過しません，乙かし先生の方法でグロブリ ンやアルブミンを追うととれは micropinocytotic vesicle の中に入って細胞の中央を active に transport されることが明らかに見えるのでしょらか.

<応 答〉東海大・病理 渡辺穈一

Immunoglobulin t marker とした場合には，明 らかに vesicle による transportation が見られま す. pinocytotic vesicle が血管腔側㧍よび基底膜側 の雨面に open している像が見られます，同じよう な現象が，I型肺胞上皮にも見られます。

<犋 疑> 北里大・薬理 鹿取 信

Radiation していない正常の動物でアルブミンが 片管外に出ていますか。

<応 答 $>$ 東海:大 病理 渡辺度一

まったくの無処置哑物の肺については，まだ， Albumin の透過性の観察は行っておりません，Radiation をあてない方の対照肺では，照射肺よりは， ずっと少いが，ある程度の血管透過があることは， 写真で示した通りです.

<追 加> 九大・病理 由中健藏 血漿成分の透過と炎症との関係のなかで, フィブ リノーゲンの透過, 沈着, 代謝の意義が大きいと思 う. 免疫グロブリン, アルブミンとともにフィブリ ノーゲンとの透過をも検討する必要があると思う。 